DOI 10.15290/cnisk.2016.01.01.01

DR HAB. JOLANTA CHWASTYK-KOWALCZYK, PROF. UJK

Uniwersytet Jana Kochanowskiego w Kielcach

\title{
Dziennikarka polskiej przestrzeni publicznej na emigracji w Londynie - Stefania Kossowska
}

\section{Streszczenie}

Jesienią 2015 r. minęła 12. rocznica śmierci Stefanii Kossowskiej, dziennikarki polskiej przestrzeni publicznej na emigracji w Londynie. Urodzona we Lwowie w 1909 r., wyedukowana w Warszawie i za granica, była wielka erudytka, rozmiłowana w czytaniu i pisaniu. Jej dokonania twórcze, działalność literacka, publicystyczna i organizacyjna jest fundamentem pejzażu życia kulturalnego polskiej diaspory na obczyźnie. Należy do pokolenia „niezłomnych”, ukształtowanego w okresie dwudziestolecia międzywojennego, zdobywała szlify dziennikarskie w takich redakcjach, jak „Bluszcz”, „ABC”, „Wieczór Warszawski”, „Prosto z Mostu". Współpracowniczka polskich czasopism emigracyjnych w Wielkiej Brytanii: „Wiadomości” M. Grydzewskiego (jako redaktor naczelna w latach 1974-1981), „Przeglądu Powszechnego”, „Orła Białego”, „Pulsu”, „Pamiętnika Literackiego”, „Dziennika Polskiego i Dziennika Żołnierza” wraz z jego dodatkiem - „Tygodniem Polskim”, paryskiej „Kultury”. Autorka m.in. książek Mieszkam w Londynie, Od Herberta do Herberta. Nagroda "Wiadomości” 1958-1990, Jak cię widzę, tak cie piszę, Galeria przodków oraz Przyjaciele $i$ znajomi. Była stała współpracowniczka Radia Wolna Europa. W 1994 r. przekazała Archiwum „Wiadomości" do Biblioteki Uniwersyteckiej w Toruniu.

Słowa kluczowe: Stefania Kossowska • polskie czasopiśmiennictwo na emigracji XX i XXI wieku • Wielka Brytania • dwudziestolecie międzywojenne w Warszawie (1918-1939) 


\title{
STEFANIA KOSSOWSKA - A JOURNALIST OF POLISH PUBLIC SPACE IN EXILE IN LONDON
}

\begin{abstract}
The autumn of 2015 marked the $12^{\text {th }}$ anniversary of the death of Stefania Kossowska, a Polish public space journalist in exile in London. Born in Lvov in 1909, educated in Warsaw and abroad, she was a great erudite, fond of reading and writing. Her creative accomplishments as well as literary, journalistic and organizational activities made the foundation of the cultural life of Polish diaspora abroad. She belonged to the "invincible" generation formed in the interwar period. Stefania Kossowska gained her journalistic skills working with the editorial board of "Bluszcz", "ABC", "Wieczór Warszawski" and "Prosto z Mostu". She was a collaborator with the Polish émigré magazines in the UK: M. Grydzewski's "Wiadomości" (editor-in-chief in the years 1974 to 1981), "Przegląd Powszechny", "Orzeł Biały", "Puls", "Pamiętnik Literacki", "Dziennik Polski i Dziennik Żołnierza" and its addendum "Tygodnik Polski", and Parisian "Kultura". Kossowska was the author, among others, of such books as: I live in London, From Herbert to Herbert. The "News" Award 1958-1990, I write you as I see you, Ancestors Gallery and Friends and acquaintances. She was a permanent collaborator with the Radio Free Europe. In 1994 she handed over the "News" archive to the University Library in Torun.
\end{abstract}

Keywords: Stefania Kossowska - Polish press in exile in XX and XXI c. • United Kingdom • interwar period in Warsaw (1918-1939)

Wraz z odzyskaniem przez Polskę niepodległości w 1918 r. nastąpił intensywny rozwój we wszystkich dziedzinach życia politycznego, społecznego, gospodarczego, naukowego, kulturalnego $\mathrm{i}$ innych. XIX-wieczne powstania narodowowyzwoleńcze, a następnie pierwsza wojna światowa, zmuszając kobiety do większej aktywności, do podjęcia ról dotychczas zarezerwowanych dla mężczyzn, naturalna koleją rzeczy uruchomiły m.in. proces ich stopniowego wyzwalania spod supremacji mężczyzn. Rozwój cywilizacji, odkrycia naukowe, ruchy rewolucyjne oraz emancypacyjne na świecie przyczyniły się do zmiany świadomości społecznej także wykształconych warstw polskiego społeczeństwa. 
Okres dwudziestolecia międzywojennego w Polsce wyznaczał, dzięki radykalnym przekształceniom społeczno-polityczno-prawnym, entuzjastycznie wspomaganym przez prasę kobieca Towarzystwa Wydawniczego „Bluszcz”, nowe standardy zachowań kobiety-obywatelki, kobiety-matki, kobiety-żony. Były one oparte wprawdzie na tradycji, jednak skonfrontowane i wzbogacone o nowe jakości życia, takie jak zdobycie praw obywatelskich, kreowanie modelu współczesnej rodziny polskiej, nowego typu wykształconej kobiety, propagowanie pracy zawodowej kobiet. Możliwość zdobycia wyższego wykształcenia przez kobiety dawała szansę wykorzystania ich potencjału intelektualnego we współtworzeniu najszerzej pojętej kultury narodowej ${ }^{1}$, a także odegrania wielkiej roli, jaka miały do spełnienia wobec Ojczyzny, wobec rodziny, wreszcie wobec siebie samych.

Stefania Kossowska, $z$ domu Szurlej, pochodziła $z$ inteligenckiej rodziny. Urodziła się 23 września 1909 r. we Lwowie, zmarła 15 września 2003 r. w Londynie - miała to szczęście, że przyszła na świat w tym właśnie czasie. Jej dzieje, wyznawane idee i etos, książki, praca dziennikarska, służba piórem sa znakomitym odzwierciedleniem możliwości, jakie dała naszym rodaczkom Konstytucja Rzeczypospolitej Polskiej z 17 marca 1921 r. i ustawa Sejmu $z$ dnia 1 lipca tego samego roku². Polki stały się równouprawnionymi obywatelkami, cieszącymi się pełnią praw politycznych i cywilnych. Młoda Stefania Szurlejówna skorzystała $z$ nich w pełni. Kossowska należy jednak do grona rzadko przywoływanych $\mathrm{w}$ piśmiennictwie naukowym, zapomnianych animatorek życia kulturalnego, a więc i politycznego, choć przyczyniła się w istotny sposób do zachowania polskiej tożsamości narodowej na obczyźnie w czasie i po zakończeniu II wojny światowej. Doczekała się nielicznych naukowych opracowań na swój temat. Do ciekawszych należy dedykowana jej publikacja, zatytułowana $\mathrm{Pa}$ -

1 Pojęcie „kultury” według Alfreda Louisa Kroebera, rozumiejącego ja jako aspekty funkcjonowania człowieka w sferze duchowej i materialnej, obejmującej obszar religii, polityki, gospodarki, sztuki, nauki, technologii, wychowania, języka, obyczajów itp. Za: A. L. Kroeber, Istota kultury, Warszawa 2002, s. 19-21.

2 Szerzej zob. J. Chwastyk-Kowalczyk, „Bluszcz” w latach 1918-1939. Tematyka społeczna oraz problemy kultury i literatury, Kielce 2003, s. 68. 
ni Stefa, wydana w Londynie w 1999 r. przez Polską Fundację Kulturalna, a także artykuł Beaty Kwieczko pt. Wybitna postać polskiej emigracji $w$ Londynie, zamieszczony w „Przeglądzie Polsko-Polonijnym" z 2014 r. ${ }^{3}$ Kossowska zaistniała w mediach, w polskiej przestrzeni publicznej ${ }^{4}$, kiedy przekazała pod koniec lat 90. XX w. archiwum londyńskich „Wiadomości” Uniwersytetowi Mikołaja Kopernika w Toruniu. 12. rocznica śmierci, przypadajaca jesienia 2015 r., tej wielkiej erudytki, rozmiłowanej w czytaniu i pisaniu, której działalność należy uznać za fundament pejzażu życia kulturalnego polskiej diaspory na obczyźnie, jest znakomitym momentem, aby przywrócić pamięć jej dokonań twórczych literackich, publicystycznych i organizacyjnych.

Rodzina Szurlejów przeprowadziła się z Lwowa do Warszawy w 1920 r. po wojnie polsko-bolszewickiej. Codziennością Stefanii było obcowanie $z$ kultura. Wspominała po latach:

Miałam brata i we czworo wszyscyśmy bez przerwy czytali, rozmawiali o tym. Moi rodzice kupowali wszystkie książki. Chodziło się do teatru, na koncerty. I rozmowy były ciagłe na te tematy. Poza tym żyliśmy w środowisku ludzi kultury: pisarzy, dziennikarzy, artystów, muzyków $(\ldots)^{5}$.

Jej ojciec Stanisław Szurlej był adwokatem, obrońca w procesie brzeskim, związany $z$ ruchem antysanacyjnym. Stefania dzięki temu szybko dojrzała politycznie, przyznajac: To nie było życie, które sie toczyło, tylko które się bardzo intensywnie przeżywało. (...) To było życie bardzo świadomé .

Państwowe Gimnazjum i Liceum im. Juliusza Słowackiego w Warszawie ukończyła w 1927 r. Po uzyskaniu świadectwa doj-

3 B. Kwieczko, Wybitna postać polskiej emigracji $w$ Londynie, „Przegląd PolskoPolonijny" 2014, nr 5-6, s. 409-424.

$4 \mathrm{~Np}$. film dokumentalny pt. Urodziłam sie we właściwym czasie, w reżyserii T. Wudzkiego, emitowany 9 czerwca 1997 r. w programie TVP1; S. Kossowska, O „Prosto z mostu”. Rozmowa z Jerzym Pietrkiewiczem, „Kultura” 1996, nr 7-8, s. $45-50$.

5 S. Kossowska, Urodziłam się we właściwym czasie, „Archiwum Emigracji. Studia, szkice, dokumenty" 2006, z. 1-2 (7-8), s. 229-230, [Dostęp: 21.09.2014]. Dostępny w World Wide Web: <http://bit.ly/2fxjvMe>.

6 Ibidem. 
rzałości wyjechała na uniwersytet do Lozanny, gdzie przez semestr uczyła się języka francuskiego. Planowała zostać lekarzem, jednak ostatecznie podjęła studia prawnicze na Uniwersytecie Warszawskim. Zrezygnowała $z$ nich w 1934 r. z powodu przypadkowej przygody dziennikarskiej $w$ "Bluszczu". Po wielu latach Kossowska $z$ sentymentem wspominała zdobywanie szlifów dziennikarskich w redakcji tygodnika, który

(...) był bardzo szacownym pismem kobiecym $z$ duża tradycją XIXwieczną. Tam naprawdę dosyć dużo się nauczyłam praktycznie techniki dziennikarskiej, (...) mogłam widzieć, jak się pracuje ${ }^{8}$. Pamiętała także niezapomnianą atmosferę przyjemnego ładu i życzliwej pomocy ze strony redaktorek, niekłamany autorytet bardzo godnej, mądrej Stefanii Podhorskiej-Okołów ${ }^{9}$.

Przypomnieć należy, że redakcja „Bluszczu” w okresie dwudziestolecia międzywojennego zamieszczała artykuły i reportaże kształtujace postawy obywatelskie wśród swoich odbiorczyń, namawiała do udziału w wyborach do Sejmu ${ }^{10}$, co także niewatpliwie wpłynęło na poglądy i sympatie polityczne przyszłej Kossowskiej. Zawarte wtedy przyjaźnie przetrwały trudny czas wojny i pomogły w adaptacji na obczyźnie ${ }^{11}$. Z „Bluszczem” Szurlejówna współpracowała w latach 1933-1938, gdzie zamieszczała opowiadania oraz artykuły poświęcone problematyce społecznej i archi-

7 M. A. Supruniuk, Przyjaciele i znajomi pani Kossowskiej. (I ksiażki), „Archiwum Emigracji. Studia, szkice, dokumenty" 2006, z. 1-2 (7-8), s. 235, [Dostęp: 07.12.2014]. Dostępny w World Wide Web: <http://bit.ly/2fxjvMe>.

8 S. Kossowska, Urodziłam się we właściwym czasie..., op. cit., s. 231; L. Wójcik, Byliśmy niezłomni, nieprzejednani (sylwetka Stefanii Kossowskiej), „Nowe Książki" 1996, nr 11, s. 4 okładki.

9 Słowa S. Kossowskiej wypowiedziane w filmie dokumentalnym w reż. T. Wudzkiego pt. Urodziłam się we właściwym czasie, emitowanym 09.06.1997 r. w programie TVP1.

10 Por. np. J. Chwastyk-Kowalczyk, op. cit., s. 67-89; Eadem, Reportaż w „Blusz$c z u " w$ okresie dwudziestolecia międzywojennego [w:] Reportaż $w$ dwudziestoleciu międzywojennym, pod red. K. Stępnika, M. Piechoty, Lublin 2004, s. 345355; Eadem, Problemy kultury Krakowa na łamach „Bluszczu” wokresie dwudziestolecia międzywojennego [w:] Kraków - Lwów. Ksią̇̇i - czasopisma - biblioteki, t. 7, pod red. H. Kosętki, Kraków 2005, s. 444-456.

11 J. Chwastyk-Kowalczyk, „Bluszcz” w latach 1918-1939... op. cit., s. 16; mowa tu o H. Naglerowej, która po niewoli w łagrze w Kazachstanie przedostała się na Wschód $z$ armia gen. Andersa, by od 1946 r. osiąść na stałe w Londynie. 
tekturze ${ }^{12}$. Za jej debiut uważa się reportaż z wycieczki do Rumunii, Bułgarii i Konstantynopola pt. Jedziemy $w$ świat, opublikowany w 1933 r. w „Świecie Dziewcząt”13.

Koneksje ojca umożliwiły jej współpracę z codziennymi pismami warszawskimi „ABC” i „Wieczorem Warszawskim” oraz od 1935 r. z tygodnikiem literacko-satyrycznym "Prosto z Mostu”, którego założycielem i redaktorem był Stanisław Piasecki. Otwarcie przyznawała, że znalazła się tam bez żadnej literackiej, a tym bardziej ideowej "zasługi ${ }^{14}$. Za naturalne uważała, że będąc przy narodzinach tego pisma, które wizualizowało się podczas rozmów, prowadzonych w jej domu, przez S. Piaseckiego, Adolfa Nowaczyńskiego i Stanisława Strzetelskiego, będzie do niego pisała. Piaseckiego - redaktora naczelnego periodyku - bardzo ceniła za umiejętność odkrywania i wspierania młodych talentów oraz dawanie swobody pisania współpracownikom ${ }^{15}$, który czasem rzucat tylko lekko jakaś zawodowa uwage $w$ rodzaju "czy nie za długie, za dużo przymiotników", co się później bardzo przydawało' ${ }^{16}$. Jej pierwszy artykuł zatytułowany Koncert $w$ Filharmonii ukazał się już w trzecim numerze „Prosto z Mostu”. W 1935 r. wydrukowano aż 18 apolitycznych i aideologicznych ${ }^{17}$ publikacji Szurlejówny, w których odnajdujemy rozmowy $z$ artystami, reportaże, sprawozdania $z$ różnych imprez kulturalnych, recenzje. W sumie w latach 1935-1939 ukazało się 37 jej tekstów, przy czym w 1936 r. kilka $z$ cyklu Tajemnice twórczości. Współpracę $z$ antysemickim

12 S. Szurlejówna, Parlament studencki, „Bluszcz” 1933, nr 21, s. 16; Eadem, Jak pracuja kobiety? Andrée Violis, znakomita dziennikarka francuska, „Bluszcz” 1933, nr 50, s. 7; Poznań, miasto zieleni, „Bluszcz” 1934, nr 20, s. 600-603; Eadem, Najzwyklejsza historia, „Bluszcz” 1934, nr 47, s. 1462-1463; Eadem, Krew krą̇y, „Bluszcz” 1935, nr 8, s. 220-221; Eadem, Miłość słabsza od śmierci, „Bluszcz” 1938, nr 2, s. 6 (30)-7 (31).

13 Eadem, Jedziemy w świat, „Świat Dziewcząt” 1933, nr 8, s. 11-12.

14 O „Prosto z Mostu”. Rozmowa $z$ Jerzym Pietrkiewiczem [w:] S. Kossowska, Przyjaciele i znajomi, Torun 1998, s. 59-65.

15 Ibidem, s. 61-62.

16 Ibidem.

$17 \mathrm{Na}$ tę rzucająca się $\mathrm{w}$ oczy apolityczność i aideologiczność publikacji S. Szurlejówny zwrócił uwage także M. Urbanowski, Szurlejówna z „Prosto z Mostu” [w:] Pani Stefa, red. R. Habielski, K. Muszkowski, P. Kądziela, Londyn 1999, s. 24. 
tygodnikiem zakończył reportaż pt. W włoskich kościołach ${ }^{18}$ zamieszczony w piśmie w 1939 r. We Włoszech poznała Adama Kossowskiego ${ }^{19}$, z którym wzięła ślub jesienią $1938 \mathrm{r}$. Z podróży poślubnej ze słonecznej Italii, jako korespondentka zagraniczna nadsyłała swoje reportaże do wspomnianych wyżej pism warszawskich.

Po wybuchu wojny 17 września opuściła wraz $z$ rodzicami Kraj i przez Rumunię dotarła do Francji, gdzie pracowała w Ministerstwie Informacji i Dokumentacji Polskiego Rządu na Obczyźnie $^{20}$, a potem przedostała się do Wielkiej Brytanii ${ }^{21}$. W listopadzie 1939 r. Kossowski został aresztowany przez NKWD, skazany na 5 lat łagru i zesłany na Syberię. Pod koniec 1943 r. dotarł do Londynu. Kossowska po przybyciu na Wyspy Brytyjskie nadal pracowała w Ministerstwie Informacji, później jako referent do spraw literackich tego samego ministerstwa, do 1947 r. Jednocześnie współpracowała $z$ pismami, które ukazywały się na emigracji oraz polska sekcja Radia $\mathrm{BBC}$, gdzie wygłaszała regularnie pogadanki o polskich nowościach wydawniczych ${ }^{22}$. Pisywała między innymi dosyć dużo (...) propagandowych rzeczy do biuletynu "Światpolu"23.

Po zakończeniu II wojny światowej, Kossowska zdecydowała, że zostaje w Londynie. Po likwidacji placówek utrzymywanych przez polski Rząd na Uchodźstwie, w latach 1949-1953 była urzędniczką Polish University College w Londynie. W latach 50.

18 S. Szurlej-Kossowska, W włoskich kościołach, „Prosto z Mostu” 1939 nr 9, s. 6.

19 Adam Kossowski (1905-1986) artysta malarz i ceramik, przez Anglików uważany jest za brytyjskiego twórcę; po wydostaniu się z łagru w 1943 r. dotarł na Wyspy Brytyjskie, gdzie spędził resztę życia, poświęcając się głównie twórczości religijnej. Szerzej zob.: J. Chwastyk-Kowalczyk, Londyński „Dziennik Polski i Dziennik Żotnierza” 1944-1989. Gazeta codzienna jako środek przekazu komunikatów kulturowych, Kielce 2008, s. 271-273; Eadem, Uniwersalny język twórczości polskich artystów plastyków na obczyźnie [w:] Świat w obrazach. Zbiory graficzne $w$ instytucjach kultury: ich typologia, organizacja $i$ funkcje, pod red. M. Komzy, Wrocław 2009, s. 115-129; Eadem, Swiat bez granic..., „Rocznik Bibliologiczno-Prasoznawczy" 2010, nr 2/13, s. 221-244.

20 Mały słownik pisarzy polskich na obczyźnie 1939-1989, red. B. Klimaszewski, Warszawa 1992, s. 171.

${ }^{21}$ R. Habielski, Zamiast wstępu [w:] Pani Stefa... op. cit., s. 6.

22 M. A. Supruniuk, op. cit., s. 237.

${ }^{23}$ S. Kossowska, Urodziłam się we właściwym czasie..., op. cit., s. 233. 
XX w. rozpoczęła współpracę z „Wiadomościami” M. Grydzewskiego, w których przez ponad dwadzieścia lat prowadziła rubrykę $W$ Londynie, podpisywana pseudonimem Big Ben. W tygodniku drukowała także artykuły, recenzje, opowiadania i reportaże z podróży (cykl: W podróży). W 1964 r., nakładem wydawnictwa Bolesława Świderskiego, opublikowała zbiór 114 felietonów, które ukazały się w „Wiadomościach” w latach 1953-1974, zatytułowany Mieszkam $w$ Londynie ${ }^{24}$. Książka została entuzjastycznie przyjęta przez środowisko emigracyjne. Opinia Zygmunta Nowakowskiego wyrażała pogląd wielu rodaków, którzy ją przeczytali:

Big Ben (...) posiada $\mathrm{w}$ najwyższym stopniu to, co zwiemy „zdrowym chłopskim rozumem”. Umie patrzeć nadzwyczaj bystro na sprawy tego świata. Nie imponuja mu Anglicy, choć dostrzega u nich także pewne zalety. (...) Podziwiam to, że Big Ben potrafi wydoić cała treść tygodnia, że w szarzyźnie i we mgle dostrzega tyle plam, tyle gry świateł i cienia. Big Ben nie jest fotografem i nie jest karykaturzysta, ale malarzem tych pięciu dni, które dziela jeden weekend od drugiego. Kto inny przechodzi sto razy codziennie ta samą ulica, jak ślepiec, jak człowiek głuchoniemy, Big Ben zaś widzi wszystko i wszystko słyszy, przykłada ucho do piersi Londynu, bada puls, ekskursjuje, przeprowadza analizę, wie ile jest cukru i ile jest białka. Moda kobieca, kościół, ludzie, ogród zoologiczny, jubileusz, wystawa obrazów, albo psów albo kwiatów, Wimbledon, bomba atomowa, autobus, kino, itd. itd., wszystko to mieści się w stenograficznych rysunkach Big Bena, zawsze pełnych polotu, bystrości, dowcipu, inteligencji i ogłady towarzyskiej. Zna stolice Anglii lepiej niż wielu zawodowych londyńczyków. Technika pisarska najwyższej miary $(\ldots)^{25}$.

W tym samym czasie, Kossowska zaczęła również stałą współpracę $z$ Radiem Wolna Europa, które ogłosiło wówczas konkurs na esej: Dlaczego nie wracam do kraju?26. W 1954 r. Kossowska zdobyła w nim pierwsza nagrodę i została freelancerem rozgłośni. Pracowała tam aż do 1994 r., kiedy została zlikwido-

24 S. Kossowska, Mieszkam w Londynie, Londyn 1964.

25 Fragment recenzji Z. Nowakowskiego zamieszczony na okładce publikacji

S. Kossowskiej, Mieszkam w Londynie, Londyn 1964.

${ }^{26}$ S. Kossowska, Urodziłam się we właściwym czasie... op. cit., s. 233. 
wana polska sekcja RWE. Publikowała także w piśmie RWE „Na Antenie", które co miesiąc, jako samodzielna wkładka pojawiało się w „Dzienniku Polskim i Dzienniku Żołnierza”27.

Od 1969 r. z powodu choroby Grydzewskiego, a potem Michała Chmielowca przejęła obowiazki red. nacz. „Wiadomości”, by po śmierci obu redaktorów od 1974 r. prowadzić je sama do likwidacji pisma w marcu 1981 r.28. Rafał Habielski wyraził opinię, że objecie przez Kossowska redakcji tygodnika było znakiem czasu. Przejawem naturalnego nastepstwa pokoleniowego oraz zatarciem podziałów $i$ animozji przedwojennych ${ }^{29}$. Mimo, iż Kossowska nigdy nie redagowała samodzielnie żadnego pisma i była pełna obaw $^{30}$, znakomicie sobie poradziła $z$ tym wyzwaniem, jak również od 1977 r. z obowiązkami dyrektora finansowego i administracyjnego periodyku. Nie kryła, że to była praca bez niedziel, bez swiat, bez godzin, ponieważ to była typowa emigracyjna instytucja jednoosobowa ${ }^{31}$. Zajmowała się tam wszystkim, obliczała honoraria, adiustowała teksty, łamała numery, wybierała zdjęcia, ilustracje, odpisywała na listy. Generalnie kontynuowała formułę pisma przyjęta przez Grydzewskiego, jednak zamieszczała w „Wiadomościach":

(...) rzeczy, które Grydzewskiemu na pewno by się nie spodobały, (...) wiersze młodych poetów z kraju, niektórych pod prawdziwym nazwiskiem, innych pod pseudonimem. Ale o żadnej radykalnej zmianie linii programowej pisma nie mogło być mowy. Po pierwsze dlatego, że ja sama nie miałam ambicji nowatorskich, a po drugie że nie było młodych, którzy chcieliby przejąć „Wiadomości”32.

27 Por.: M. A. Supruniuk, op. cit., s. 237.

28 List Stefanii Kossowskiej do J. Chwastyk-Kowalczyk - Londyn, 03.05.1998, s. 2, prywatne archiwum autorki.

${ }^{29}$ R. Habielski, op. cit. [w:] Pani Stefa... op. cit., s. 7-8.

30 K. Muszkowski, Rozmowy przy perliczce, „Archiwum Emigracji. Studia, szkice, dokumenty" 2006, z. 1-2(7-8), s. 264, [Dostęp: 10.12.2014]. Dostępny w World Wide Web: <http://bit.ly/2fxjvMe>.

31 S. Kossowska, Urodziłam się we właściwym czasie... op. cit., s. 233; por. list Stefanii Kossowskiej do J. Chwastyk-Kowalczyk, Londyn, 12.06.2000 r. - prywatne archiwum autorki.

32 S. Kossowska, Urodziłam się we właściwym czasie... op. cit., s. 233. 
W 1973 r. została wybrana na członka jury Nagrody „Wiadomości”, gdzie zastapiła zmarłego w czerwcu tegoż roku Wacława Grubińskiego. Tadeusz Nowakowski uważał, że była tam animatorka polskiego życia kulturalnego nad Tamiza ${ }^{33}$. W latach 19761991 pełniła także funkcję przewodniczącej komisji, wymienionej wyżej nagrody, której historię opisała w książce pt. Od Herberta do Herberta. Nagroda „Wiadomości” 1958-199034.

Po zamknięciu „Wiadomości” $z$ powodów finansowych Kossowska nieprzerwanie zajmowała się pisaniem książek i artykułów do prasy emigracyjnej, m.in.: „Kultury”, „Przeglądu Powszechnego”, „Orła Białego”, „Pulsu”, „Pamiętnika Literackiego”, „Dziennika Polskiego i Dziennika Żołnierza”. Z tym ostatnim wraz z jego samoistnym dodatkiem „Tygodniem Polskim” (do1984 r. ${ }^{35}$ ) współpracowała już od 1959 r., pisząc cykl felietonów, podpisywanych pseudonimem „sk", zatytułowanych Ważne $i$ nieważne. Bardzo ceniła Jerzego Giedroycia, $z$ którego miesięcznikiem współpracowała od 1985 r., i który nie pozwalał jej „zardzewiec”36. Poza wspomnianymi już książkami, drukiem ukazały się także antologia „Wiadomości” na emigracji ${ }^{37}$ oraz wybory opowiadań, felietonów, artykułów recenzyjnych i wspomnieniowych: Jak cie widze, tak cie piszę $e^{38}$, Galeria przodków39 oraz Przyjaciele i znajomi ${ }^{40}$.

W lutym 1986 r. w wieku prawie 80 lat, Kossowska podjęła się redagowania miesięcznego dodatku do „Dziennika Polskiego

\footnotetext{
33 L. Paszkowski, Spojrzenie z dalekiej perspektywy [w:] Pani Stefa... op. cit., s. 133.

34 Od Herberta do Herberta. Nagroda „Wiadomości” 1958-1990, oprac. i przedmowa S. Kossowska, postscriptum T. Nowakowski, Londyn 1993.

35 List Stefani Kossowskiej z 22 lipca 1984 roku [w:] S. Kossowska, Definicja szczęścia. Listy do Anny Frajlich 1972-2003, do druku przygotowała, słowem wstępnym i przypisami opatrzyła A. Supruniuk, Torun 2007, s. 82.

36 Absolutna wolność. Stefania Kossowska o „Środzie Literackiej” i ksiażkach. Rozmowa Mirosława A. Supruniuka ze Stefania Kossowska, „Archiwum Emigracji. Studia, szkice, dokumenty" 2006, z. 1-2 (7-8), s. 247, [Dostęp: 20.11.2014]. Dostępny w World Wide Web: <http://bit.ly/2fxjvMe>.

37 „Wiadomości” na emigracji. Antologia prozy 1940-1967 w wyborze i z przedmowa S. Kossowskiej, Londyn 1968.

38 S. Kossowska, Jak cie widzę, tak cie piszę, Londyn 1973.

39 Eadem, Galeria przodków, Warszawa 1991.

40 Eadem, Przyjaciele i znajomi, Torun 1998.
} 
i Dziennika Żołnierza” - „Środy Literackiej”. Ten całkowicie niezależny dodatek prowadziła, mimo poważnych kłopotów ze zdrowiem, aż do sierpnia 2002 r. ${ }^{41}$. Przez szesnaście lat ukazało się aż dwieście numerów tego dodatku literackiego.

Kossowska od 1986 do 1992 r. była członkiem Związku Pisarzy Polskich na Obczyźnie, a w latach 80. XX w. pełniła funkcje doradcy literackiego Polskiej Fundacji Kulturalnej w Londynie. Od 1990 r. publikowała również w pismach ukazujących się w Polsce: „Dekadzie Literackiej”, „Tygodniku Powszechnym”, „Więzi” czy „Gazecie Wyborczej”42.

Przyjmowała wielu gości z Polski, którzy przyjeżdżali do Londynu: biednych studentów, magistrów $i$ świeżo upieczonych doktorantów historii $i$ polonistyki, których zaciekawiła atrakcja emigracji literackiej, artystycznej i politycznej43. W 1994 r. przekazała Archiwum „Wiadomości” wraz z wyposażeniem pokoju redakcyjnego i pamiątkami po redaktorach, przy wsparciu finansowym Fundacji z Brzezia Lanckorońskich, które zostało przewiezione do Biblioteki Uniwersyteckiej w Toruniu ${ }^{44}$. Od 1995 r. współredagowała serię wydawnicza „Archiwum Emigracji”, którą wydawał Uniwersytet Mikołaja Kopernika w Toruniu.

Za swoja działalność literacka i redaktorska Kossowska otrzymała wiele nagród i odznaczeń, dla przykładu: nagrodę Fundacji im. Alfreda Jurzykowskiego w 1980 r., nagrodę im. Stefana Badeniego w 1984 r., nagrodę „Kultury” im. Zygmunta Hertza w 1993 r. Edward Raczyński w 1980 r. nadał jej Krzyż Oficerski Polonia Restituta. 14 lat później została odznaczona przez Lecha Wałęsę Krzyżem Komandorskim Orderu Odrodzenia Polski. W 1997 r. Senat Uniwersytetu w Toruniu przyznał jej Medal „Za Zasługi Położone dla Rozwoju UMK"45. Zmęczona 60-letnią pracą zawodowa, zmarła w Antokolu w Londynie 15 września 2003 r.

\footnotetext{
41 List Stefanii Kossowskiej z 2 lutego 1986 roku [w:] S. Kossowska, Definicja szczęścia. Listy do Anny Frajlich... op. cit., s. 101; opis zawartości „Środy Literackiej”, autorów zob. J. Chwastyk-Kowalczyk, Londyński „Dziennik Polski i Dziennik Żotnierza” 1944-1986... op. cit., s. 94-96.

42 M. A. Supruniuk, op. cit., s. 239.

43 K. Muszkowski, Złote żniwo państwa Kossowskich [w:] Pani Stefa... op. cit., s. 12.

${ }^{44}$ K. Muszkowski, Rozmowy przy perliczce... op. cit., s. 267.

45 M. A. Supruniuk, op. cit., s. 238.
} 
w wieku 94 lat. Została pochowana obok męża46 na cmentarzu w opactwie karmelitów w Aylesford ${ }^{47}$.

Reasumujacc. Kossowska - animatorka polskiego życia intelektualnego na emigracji, należąca do generacji twórców wyrosłych w czasach suwerenności, dojrzewajaca w Polsce niepodległej, poddana ciężkiej próbie wojennej tułaczki oraz podejmujaca po zakończeniu II wojny światowej dramatyczne decyzje o pozostaniu na obczyźnie - swym uniwersalnym widzeniem świata, twórczością, a także działaniami w sferze publicznej, dała świadectwo przynależności polskiej kultury do świata zachodniego. Nigdy nie dała się uwieść przedwojennej polskiej prowincjonalnej nacjonalistycznej perspektywie. Obdarzona wieloma talentami, konsekwentnie syntetyzowała uniwersalne a zarazem polskie wartości w swoich polifonicznych wielogatunkowych wypowiedziach, komentarzach, obserwacjach, szeptach i spojrzeniach. Dzięki takim hybrydycznym postaciom ojczyzna gromadzi swoje ślady, a Polska odzyskuje pamięćt8.

\section{Bibliografia}

\section{Archiwalia prywatne}

List Stefanii Kossowskiej do Jolanty Chwastyk-Kowalczyk, Londyn, 03.05.1998, prywatne archiwum autorki.

List Stefanii Kossowskiej do Jolanty Chwastyk-Kowalczyk, Londyn, 12.06.2000 r., prywatne archiwum autorki.

\section{Wspomnienia, pamiętniki i zbiory źródel}

Kossowska S., Definicja szczęścia. Listy do Anny Frajlich 1972-2003, do druku przygotowała, słowem wstępnym i przypisami opatrzyła A. Supruniuk, Toruń: Uniwersytet Mikołaja Kopernika, 2007, ISBN 97883-231-2073-5.

46 Adam Kossowski zmarł 31 marca 1986 r.

47 M. Bielicka, Niedzielne spotkania, „Archiwum Emigracji. Studia, szkice, dokumenty" 2006, z. 1-2 (7-8), s. 275, [Dostęp: 20.11.2014]. Dostępny w World Wide Web: <http://bit.ly/2fxjvMe>.

48 Ks. B. Miązek, Ksiażka ważna i potrzebna, „Pamiętnik Literacki” 2014, t. 47, s. 163 . 
Kossowska S., Galeria przodków, Warszawa: Biblioteka „Więzi”, 1991, ISBN 83-85124-56-X.

Kossowska S., Jak cię widze, tak cię piszę, Londyn 1973.

Kossowska S., Mieszkam w Londynie, Londyn 1964.

Kossowska S., Przyjaciele i znajomi, Toruń: Biblioteka Uniwersytecka UMK, 1998, ISBN 83-231-0961-3.

„Wiadomości” na emigracji. Antologia prozy 1940-1967, w wyborze i z przedmowa S. Kossowskiej, Londyn: Polska Fundacja Kulturalna, 1968.

\section{Publicystyka prasowa}

Günther W., [recenzja bez tytułu], „Życie” 1957, nr 13.

Jovanka Čirlič D., Kobieta z kurzu, „Gazeta Wyborcza” z dn. 26.05.2003.

Kossowska S., O „Prosto $z$ mostu”. Rozmowa $z$ Jerzym Pietrkiewiczem, „Kultura” 1996, nr 7-8.

Kossowska S., Pani Maria, „Kultura” 1997, nr 5 (596).

Naglerowa H., Blisko i daleko, „Wiadomości” 1953, nr 29 (381).

Naglerowa H., Nieprzemijalne wartości, „Życie” 1957, nr 23.

Nowakowski Z., Poezja chleba powszedniego, „Dziennik Polski i Dziennik Żołnierza" 1957, nr 51.

Szurlej-Kossowska S., W włoskich kościołach, „Prosto z Mostu” 1939, nr 9.

Szurlejówna S., Jak pracuja kobiety? Andrée Violis, znakomita dziennikarka francuska, „Bluszcz” 1933, nr 50.

Szurlejówna S., Jedziemy w świat, „Świat Dziewcząt” 1933, nr 8.

Szurlejówna S., Krew krąży, „Bluszcz” 1935, nr 8.

Szurlejówna S., Miłość słabsza od śmierci, „Bluszcz” 1938, nr 2.

Szurlejówna S., Najzwyklejsza historia, „Bluszcz” 1934, nr 47.

Szurlejówna S., Parlament studencki, „Bluszcz” 1933, nr 21.

Szurlejówna S., Poznań, miasto zieleni, „Bluszcz” 1934, nr 20.

Wójcik L., Byliśmy niezłomni, nieprzejednani (sylwetka Stefanii Kossowskiej), „Nowe Ksiażki” 1996, nr 11.

\section{Opracowania}

Chwastyk-Kowalczyk J., „Bluszcz” w latach 1918-1939. Tematyka społeczna oraz problemy kultury i literatury, Kielce: Wydawnictwo Akademii Świętokrzyskiej, 2003, ISBN 83-7133-212-2. 
Chwastyk-Kowalczyk J., Londyński „Dziennik Polski i Dziennik Żołnierza” 1944-1989. Gazeta codzienna jako środek przekazu komunikatów kulturowych, Kielce: Wydawnictwo Akademii Świętokrzyskiej, 2005, ISBN 83-7133-261-0.

Chwastyk-Kowalczyk J., Problemy kultury Krakowa na łamach „Bluszczu” w okresie dwudziestolecia międzywojennego [w:] Kraków Lwów. Książki - czasopisma - biblioteki, pod red. H. Kosętki, Kraków 2005, t. 7.

Chwastyk-Kowalczyk J., Reportaż w „Bluszczu” w okresie dwudziestolecia międzywojennego [w:] Reportaż $w$ dwudziestoleciu międzywojennym, pod red. K. Stępnika, M. Piechoty, Lublin 2004.

Chwastyk-Kowalczyk J., Uniwersalny język twórczości polskich artystów plastyków na obczyźnie [w:] Świat w obrazach. Zbiory graficzne $w$ instytucjach kultury: ich typologia, organizacja $i$ funkcje, pod red. M. Komzy, Wrocław 2009.

Kroeber A. L., Istota kultury, Wyd. 3, Warszawa: Wydawnictwo Naukowe PWN, 2002, ISBN 83-01-04107-2.

O „Prosto z mostu”. Rozmowa $z$ Jerzym Pietrkiewiczem [w:] S. Kossowska, Przyjaciele i znajomi, Torun 1998.

Od Herberta do Herberta. Nagroda „Wiadomości” 1958-1990, oprac. i przedmowa S. Kossowska, postscriptum T. Nowakowski, Londyn: Polska Fundacja Kulturalna, 1993, ISBN 0-85065-255-3.

Pani Stefa, red. R. Habielski, K. Muszkowski, P. Kądziela, Londyn: Polska Fundacja Kulturalna, 1999, ISBN 0-85065-254-5.

Urbanowski M., Szurlejówna z „Prosto z Mostu” [w:] Pani Stefa, red. R. Habielski, K. Muszkowski, P. Kądziela, Londyn 1999.

Wasiak-Taylor R., Dzieje nagrody literackiej 1951-2011 Zwiazku Pisarzy Polskich na Obczyźnie, Londyn: Wyd. ZPPnO, 2011, ISBN 978-09570372-0-5.

\section{Artykuły naukowe}

Chwastyk-Kowalczyk J., Świat bez granic..., „Rocznik BibliologicznoPrasoznawczy" 2010, nr 2/13, ISSN 2080-4938.

Kwieczko B., Wybitna postać polskiej emigracji $w$ Londynie, „Przegląd Polsko-Polonijny” 2014, nr 5-6, ISSN 2083-3121.

Miązek B., Książka ważna i potrzebna, „Pamiętnik Literacki” 2014, t. 47, ISSN 0031-0514. 


\section{Inne, pomocnicze materiały informacyjne}

Danel J. K., Druga Wielka Emigracja 1945-1990. Słownik biograficzny, Zamość: Wydawnictwo Officina Simonidis, 2011, t. 2, ISBN 978-8361893-56-1.

Kowalik J., Bibliografia czasopism Polskich wydanych poza granicami Kraju od września 1939 roku, Lublin: Katolicki Uniwersytet Lubelski, 1976, t. 4.

Mały słownik pisarzy polskich na obczyźnie 1939-1989, red. B. Klimaszewski, Warszawa: Wydawnictwo Interpress, 1992, ISBN 83-2232418-9.

Urodziłam się we właściwym czasie, w reż. Tadeusza Wudzkiego, film dokumentalny emitowany 9 czerwca 1997 r. w programie TVP1.

\section{Zasoby internetowe}

Absolutna wolność. Stefania Kossowska o "Środzie Literackiej” i ksiażkach. Rozmowa Mirosława A. Supruniuka ze Stefania Kossowska, „Archiwum Emigracji. Studia, szkice, dokumenty” 2006, z. 1-2 (7-8), s. 247, [Dostęp: 20.11.2014]. Dostępny w World Wide Web: <http:/ / bit.ly/2fxjvMe>.

Bielicka M., Niedzielne spotkania, „Archiwum Emigracji. Studia, szkice, dokumenty" 2006, z. 1-2 (7-8), s. 275, [Dostęp: 20.11.2014]. Dostępny w World Wide Web: <http://bit.ly/2fxjvMe>.

Kossowska S., Urodziłam sie we właściwym czasie, „Archiwum Emigracji. Studia, szkice, dokumenty” 2006, z. 1-2 (7-8), s. 229-230, [Dostęp: 07.12.2014]. Dostępny w World Wide Web: <http://bit.ly/ 2fxjvMe>.

Muszkowski K., Rozmowy przy perliczce, „Archiwum Emigracji. Studia, szkice, dokumenty" 2006, z. 1-2 (7-8), s. 264, [Dostęp: 10.12.2014].

Dostępny w World Wide Web: <http:/ / bit.ly/2fxjvMe>.

Supruniuk M. A., Przyjaciele i znajomi pani Kossowskiej. (I ksiażki), „Archiwum Emigracji. Studia, szkice, dokumenty" 2006, z. 1-2 (7-8), s. 235, [Dostęp: 07.12.2014]. Dostępny w World Wide Web: $<$ http:/ / bit.ly/2g3rTXE >. 